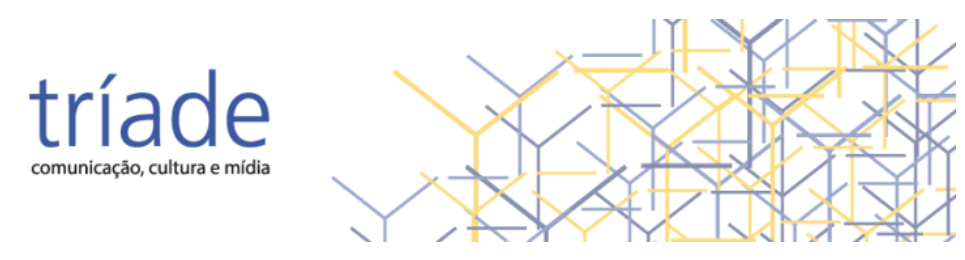

\title{
Balizas do campo comunicação e política
}

\author{
Beacons from the field of political communication \\ Delimitación del campo comunicación política
}

\begin{abstract}
Maria Helena Weber - Universidade Federal do Rio Grande do Sul | Porto Alegre | Rio Grande do Sul | Brasil | maria.weber@ufrgs.br |

https://orcid.org/0000-0002-7921-4524.
\end{abstract}

Resumo: O cabimento desse texto está relacionado à reflexão sobre aspectos que permitem identificar a consolidação do Campo da Comunicação e Política como um espaço interdisciplinar e substantivo à compreensão de fenômenos sociais, culturais, políticos e econômicos engendrados no trígono Estado, Mídia e Sociedade. Nessas três dimensões de poder podem ser identificados processos de comunicação e coerção singulares relacionados à visibilidade e credibilidade. $\mathrm{O}$ texto privilegia então a comunicação institucional, a comunicação societal, a comunicação midiática, a comunicação pública e aspectos históricos. O texto apresenta aspectos da complexidade teórica e metodológica de um campo que abrange regimes políticos, mídias, sistemas e produtos de comunicação, assim como a sua constituição no Brasil.

Palavras-chave: Comunicação e Política. Teorias da Comunicação. Mídias. Comunicação Pública.

Abstract: The appropriateness of this text is connected to some reflections on issues which allow identifying the consolidation of the Field of Communication and Politics as an interdisciplinary and meaningful space to understand the social, cultural, polítical, and economic phenomena framed in the trine of State, Media, and Society. Within these three dimensions of power unique communication and coercion processes, related to visibility and credibility, can be identified. Thus, this text emphasizes institutional communication, societal communication, media communication, public communication, and also historical aspects intending to show the theoretical and methodological complexities of a field that comprises polítical regimes, media, systems, and communication products, especially in Brazil.

Keywords: Communication and Politics. Communication Research. Media. Public Communication.

Resumen: El presente texto se dedica a reflexionar acerca de aspectos que permiten identificar la consolidación del campo de la Comunicación Política como espacio interdisciplinario y fundamental para la comprensión de fenómenos sociales, culturales, políticos y económicos, engendrados en el trinomio Estado-medios de comunicación-sociedad. En esas tres dimensiones de poder, se pueden identificar procesos particulares de comunicación y coerción 
vinculados con la visibilidad y con la credibilidad. Por lo tanto, el presente texto subraya la comunicación institucional, la comunicación social, la comunicación mediática, la comunicación pública y aspectos históricos con el objeto de poner de relieve la complejidad teórica y metodológica de un campo que abarca regímenes políticos, medios, sistemas y productos de comunicación especialmente en Brasil.

Palabras clave: Comunicación política. Investigación em Comunicación. Media. Comunicación pública.

Recebido em agosto 2020 - Aprovado em agosto 2020. 
A primazia da aparência é um fato da vida cotidiana do qual nem o cientista nem o filósofo podem escapar, ao qual têm sempre que voltar em seus laboratórios e em seus estudos, e cuja força fica demonstrada

pelo fato de nunca ter sido minimamente alterada ou desviada por qualquer coisa que eles tenham descoberto quando dela se afastaram. Hanna Arendt (1992, p. 21).

\section{Introdução}

Política é prática e discurso imanentes à vida que se movimenta em comunicação, relações e tecnologia. O campo denominado comunicação e política é herdeiro de linhagens mantidas por rituais, símbolos, discursos, propaganda, notícias, acontecimentos, espetáculos e meios de comunicação que acompanham guerras, religiões, democracias, ditaduras, sociedades, instituições e atores políticos no exercício de poder. Do registro impresso à ubiquidade da informação digital, o campo abriga questões sobre a amplitude e os limites do poder da comunicação num Estado republicano ou ditatorial; da formação de opiniões individuais à opinião pública; dos pactos entre mídias e governos à censura da imprensa; da visibilidade planejada ou fortuita à formação da imagem pública; da liberdade de manifestações sociais à sua repressão.

Ações políticas dependem de espaços de visibilidade e de interlocução proporcionados pelos meios de comunicação massivos e mídias digitais; por sistemas institucionais próprios à difusão de discursos e de produtos publicitários estrategicamente dirigidos a públicos específicos. É no movimento destes processos, que agregam e rechaçam opiniões e apoios, que os estudos em comunicação e política se consolidam.

Campo é um conceito seminal na obra de Pierre Bourdieu e aqui

(U) apropriado em parte, já que mesmo sem refletir sobre o "campo da comunicação" o autor legou estudos sobre opinião pública, televisão e sobre o campo do jornalismo (BOURDIEU, 1994). O campo Comunicação e Política pode ser entendido como espaço interdisciplinar entre as ciências sociais, ciência política e os estudos da comunicação, assim conformado na salutar 
tensão entre teorias, métodos, posições de agentes e seus capitais simbólicos, com diferentes graus de autonomia e dependência. Para a Comunicação, a política é parte da sua natureza, é pauta jornalística permanente, é um locus profissional e matéria prima das relações entre Estado e sociedade. Para a Ciência Política, esta vinculação importa devido à necessidade de visibilidade e credibilidade por parte do Estado, instituições e atores políticos, que dependem de estratégias de comunicação, da produção de comunicação e ações comunicacionais e especialistas.

Refletir sobre a amplitude do campo Comunicação e Política é o desafio deste trabalho e, para tanto, importa recuperar balizas teóricas, históricas e funcionais à sua evolução, mesmo que correndo o risco. Persigo a hipótese de que as teorias e modelos da comunicação tentam responder, desde os seus primórdios, aos efeitos exercidos pelos espetáculos, propaganda e a notícia na formação e controle da opinião. Entre os grupos sociais, a sociedade organizada, instituições, xamãs e governantes circula, desde sempre, a linguagem do poder na forma de símbolos, rituais e imagens que, também, contam a história da humanidade. Democracias e totalitarismos executam diferentes formas de comunicação, persuasão e dominação.

Esse texto foi organizado através de combinações entre feitos da história e da política e a relação com o desenvolvimento do campo, Comunicação e Política, considerando especialmente, questões de visibilidade e credibilidade (WEBER, 2006) que incidem sobre exercícios e desejos de poder das instituições e atores políticos para informar, persuadir e conformar determinadas realidades; estabelecer relações políticas, sociais e midiáticas; produzir propaganda, eventos e notícias para conquistar a opinião pública. Pretendo problematizar fenômenos sociais, culturais, políticos e econômicos engendrados no trígono Estado, Mídia e Sociedade, para identificar os processos de comunicação e coerção singulares, desenvolvidos através da produção estratégica de comunicação. Balizas 
históricas e conceituais permitem delimitar o campo através de temas de pesquisa que moldam o campo e demarcam a sua importância para a Ciência Política e a Comunicação.

A abrangência desse texto é necessariamente arbitrária e incompleta, mas persegue-se a coerência mínima - histórica e conceitual, através da delimitação da comunicação e da política em um campo interdisciplinar. A título de organização, abordei cinco dimensões abrigadas no campo Comunicação e Política que permitem identificar as relações de poder entre política, meios de comunicação e sociedades, a saber: a comunicação política de caráter geral; a comunicação pública entendida como hipótese agregadora das democracias; a comunicação institucional que aborda meios e estratégias desenvolvidas por instituições e atores políticos, na paz e na guerra; a comunicação midiatizada executada por organizações midiáticas e imprensa, como espaço privilegiado de visibilidade e locução, do qual dependem atores políticos e sociais, e a comunicação societal identificada em grupos, mobilizações, movimentos sociais e, especialmente, a opinião pública. Na última parte deste texto, a síntese destas dimensões na trajetória formal do campo comunicação e política no Brasil.

\section{0 campo Comunicação e Política}

A constituição do campo Comunicação e Política possui bases interdisciplinares e é uma das principais instâncias de análise e compreensão de fenômenos históricos, sociais, políticos, econômicos e comunicacionais. Aos métodos das ciências políticas e sociais acopla-se a perspectiva cultural da comunicação que permite qualificar as análises sobre o exercício de poderes dependentes de atos de visibilidade, comunicação e propaganda essenciais às democracias e totalitarismos. Os estudos interdisciplinares permitem analisar as estratégias e a produção de peças destinadas ao entendimento ou à manipulação da opinião, em respeito ou detrimento do interesse público. Esses procedimentos exigem 
dos pesquisadores da comunicação algum domínio de teorias e métodos consolidados nas ciências sociais. Para os cientistas políticos, geralmente o interesse recai sobre as mídias e a veiculação de temas políticos sem, necessariamente, a inclusão de avanços metodológicos da área de Comunicação. Mesmo com estes limites, o campo propicia um dos exercícios de interdisciplinaridade melhor sucedidos, porque permite entender a inevitável dependência da política em relação à comunicação, assim como os estudos da comunicação dependem das ciências sociais.

O binômio conceitual - comunicação política - diz da incapacidade de compreender fenômenos da política e da sociedade quando isolados da interferência comunicacional e midiática que detém o poder de mostrar, ampliar, restringir ou anular a visibilidade destes fenômenos. Do mesmo modo, o entendimento sobre autonomia, vínculos e dependências das organizações mediáticas em relação às instituições políticas permitiu, historicamente, expor os mitos de imparcialidade e neutralidade da imprensa (impressa e digital) em relação à economia e à política.

Estudos e achados sobre as consequências da interdependência entre os poderes políticos e midiáticos integram o rol das pesquisas que desagradam aos poderes, porquanto tornam visíveis intenções, identificam estratégias e formatos utilizados para "a manipulação, o controle, o silenciamento e a repressão" da sociedade (WEBER; COELHO; LOCATELLI, 2017, p. 12). As pesquisas mostram a força da comunicação para as democracias e a mobilização da sociedade organizada, ou não. Esse é um campo de tensões mantidas em níveis alternados de visibilidade da política realizada no Estado, através de mídias e quando expressa pela sociedade.

(U) Como se houvesse diferentes realidades, considerando que em cada um destes níveis são desencadeados processos de interpretação e visibilização desejados pelo Estado; fragmentados pelas mídias e vivenciados pela sociedade. Em diferentes momentos históricos das democracias, dos totalitarismos é possível identificar a mistura estratégica entre propaganda, comunicação e informação, assim como a preponderância de interesses 


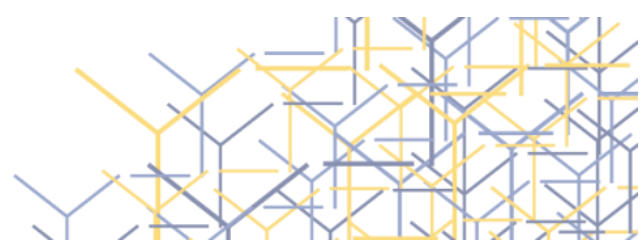

privados sobre o interesse público.

O campo abriga temas que tensionam os problemas e rotinas da política e da comunicação, que se complementam e se confrontam. $\mathrm{Na}$ dimensão da comunicação institucional competem os regimes políticos e as políticas de comunicação obedientes a estratégias e projetos políticos de manutenção do poder; na comunicação midiatizada - que designa tanto meios de comunicação tradicionais como rádio, televisão, quanto plataformas e mídias digitais -, há uma submissão da política à lógica da linguagem e da produção; a comunicação societal, própria das ações comunicativas entre pessoas, a sociedade civil organizada, os grupos sociais, movimentos sociais e possui como expressão principal a Opinião Pública, que pode ser controlada pelo Estado, tornada visível pelas mídias e, sempre, criar sua própria comunicação. A dimensão da comunicação pública permite, a título de hipótese, identificar a qualidade das democracias.

Essas dimensões permitem problematizar questões caras às ciências sociais e humanas, como poder, visibilidade, credibilidade e realidade que historicamente assumem diferentes denominações e permitem formular a hipótese de que o impacto dos meios de comunicação e a difusão de mensagens em linguagens e estéticas próprias impulsionaram e impulsionam as pesquisas e o pensamento em torno dos efeitos possíveis sobre o comportamento e as ações da sociedade.

Harold Laswell, autor de extensa obra sobre propaganda, linguagem, símbolos, significados, meios e efeitos, construiu um dos mais importantes paradigmas visando à compreensão dos atos de comunicação. Martino

<U (2012, p. 4) aponta seu interesse para a Comunicação "capaz de intervir no cotidiano da tomada de decisões" e "como auxiliar na compreensão da política, seja em seu aspecto partidário-eleitoral, seja como o todo das relações de poder, pressão e decisões na sociedade".

Coexistem, atualmente, muitas versões sobre o mesmo fato ou o mesmo discurso em busca da melhor explicação sobre a realidade, capazes 
de fortalecê-los ou destruí-los. A opinião pública (como sondagem, manifestação ou em debate público) é o indicador da apreensão e reações sobre as versões apresentadas. A pesquisa sobre a comunicação da política permite ingressar nas estratégias discursivas e semióticas dos enunciados identificados em produtos jornalísticos, publicitários, eventos e no próprio discurso que tentam promover uma realidade exclusiva. A verdade é fundamental para a credibilidade das instituições políticas e da produção midiática junto ao leitor, espectador, mercado, opinião pública. Assim, o poder insidioso dos meios de comunicação ocorre na tensão entre pactos e disputas com os outros poderes, ora na perspectiva empresarial, ora na perspectiva simbólica, ora na jornalística (imprensa). O recorte da realidade e a decisão sobre o que será dado a ver e quem será visto estabelecem um jogo perverso entre a visibilidade e a cegueira que alia tecnologia, desejo e imaginário a competências estéticas e informacionais e destas somos reféns por opção. Tudo isso indica a complexidade do campo Comunicação e Política.

O cabimento da pesquisa no campo da Comunicação e Política é relevante devido à problematização possível de questões específicas à comunicação que incidem sobre as práticas de instituições e atores políticos, em busca de visibilidade e apoio. Visibilidade e credibilidade (WEBER, 2006) formam um binômio importante para a pesquisa desse campo, atravessada por dispositivos digitais que ampliam a visibilidade de instituições e atores políticos, sociais e midiáticos, independentemente de seus interesses. Neste sentido, a credibilidade desejada é colocada em dúvida, na medida em que a apropriação, confirmação ou deturpação de informações é incontrolável. Em risco, e cada vez mais, a veracidade de qualquer discurso político para o qual, segundo Charaudeau (2006, p. 120), "a credibilidade é particularmente complexa" na medida em que o discurso de um político depende da sinceridade, performance e eficácia, e "o desafio consiste em tentar persuadir determinado público de que se tem certo poder". Nesta complexidade, cabe incluir o discurso de públicos que falam 
nas redes sociais, duvidam e apoiam a partir de interesses particulares.

A dimensão comunicacional imanente aos grandes eventos da humanidade atraiu pensadores e pesquisadores de vários campos científicos, sendo que o ingresso de um pesquisador do campo da comunicação é evidenciado, especialmente no Brasil, a partir da institucionalização da área e das profissões vinculadas.

\section{No Brasil, um campo consolidado}

A área da comunicação começa a interessar o país a partir da década de 60, impulsionada por pensadores intrigados com o poder dos meios de comunicação, com a transformação das linguagens e a proximidade da tecnologia como nos diziam os textos sobre fundamentos científicos da comunicação, a cibernética e McLuhan (1971) com sua aldeia global.

O artigo fundamental à compreensão do campo - Mídia e Política no Brasil: textos e agenda de pesquisa assinado por Rubim e Azevedo (1998) - concretiza uma das primeiras aproximações entre dois pesquisadores da política e da comunicação. O artigo é emblemático porque recupera temas e produções que marcam os primeiros passos deste tipo de pesquisa que tem seu desenvolvimento no Brasil controlado pela ditadura presente no ambiente acadêmico e na censura à imprensa, à produção intelectual. Rubim e Azevedo (1998, p. 189) afirmam que a ditadura militar "reprimiu as interações possíveis entre política e mídia" e que "este impedimento da política livremente se realizar na sociedade em seus novos espaços (virtuais) de sociabilidade, engendrados pelas mídias determinou, por

(U) conseguinte, que a eclosão significativa desta temática de estudos guardasse uma íntima conexão com a redemocratização do país [...]".

Embora possam ser identificados textos, revistas e produção intelectual na área da comunicação em toda a história do país, de acordo com Rubim e Azevedo (1998) o início da configuração do campo comunicação política ocorre a partir do I Simpósio Nacional de Pesquisa em 
Comunicação, (ECA/USP, 1990) promovido pela associação CEBELA ${ }^{1}$. Os pesquisadores podiam debater livremente na recém-inaugurada democracia, com a eleição de Fernando Collor de Mello (1989), que foi cassado em 1991. Alguns textos deste encontro fizeram a histórica edição 11 (1990) da revista Comunicação \& Política - Comunicação e Poder televisão e eleições presidenciais -, um marco para esses estudos, tendo sido publicada em duas edições. A revista era editada desde 1984.

A consolidação desse grupo - então denominado Comunicação e Poder -, se efetiva a partir de reunião promovida pelo CEBELA, na FACOM/UFBA, em Salvador (1991) e institucionalizado como GT Comunicação e Política, no I congresso da COMPÓS² (ECO/UFRJ, 1992). Assim se mantém (até 2020), com muitas mudanças e apesar de reclivagens bienais às quais é submetido, como todos os grupos de trabalho, quando então há exclusão de alguns e ingresso de novos.

Antes desses marcos, as temáticas vinculadas à comunicação e política já eram abordadas na Intercom ${ }^{3}$ cujas reuniões nacionais, assim como a Abepec (1973-1986) faziam parte da resistência intelectual, sendo realizadas ainda sob o medo do aparato repressivo, já que pensar e debater era processos controlados. Atualmente, na Intercom, persistem dois grupos de trabalho do campo: Políticas e Estratégias de Comunicação e Economia Política da Informação, Comunicação e Cultura.

No mundo todo, o desenvolvimento do capitalismo pós-guerra e o poder dos meios de comunicação, especialmente a televisão, provocaram intelectuais de todas as áreas de conhecimento e incentivaram a formação de profissionais. Esta explosão ocorre especialmente nos anos 60, mas a <U participação do Brasil quanto à pesquisa e à produção científica é

\footnotetext{
${ }^{1}$ CEBELA - Centro Brasileiro de Estudos Latino-Americanos, que tinha por objetivo reunir cientistas sociais, cientistas políticos, comunicadores sociais, educadores e intelectuais.

2 COMPOS - Associação Nacional dos Programas de Pós-Graduação em Comunicação, mantida pelos programas de pós-graduação que, até 2019, somavam 51 em stricto sensu. (www.compos.org.br).

3 INTERCOM - Sociedade Brasileira de Estudos Interdisciplinares da Comunicação, fundada em 1977.
} 


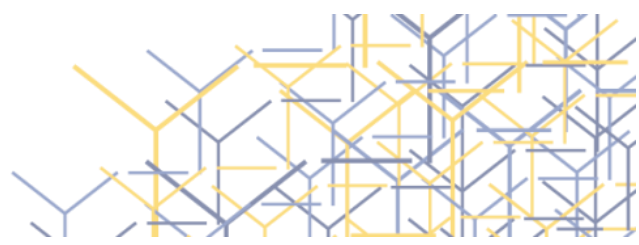

praticamente inexistente. Cabe assinalar uma das primeiras produções importantes para o aporte científico do campo da comunicação e política que foi a pesquisa desenvolvida entre a $A_{B E P E C}{ }^{4}$ e a $\operatorname{PUCRS}^{5}$ sobre a televisão brasileira relatada no livro Televisão e Capitalismo (CAPPARELLI,1982), citado por José Marques de Melo (2016, p. 76) como o "primeiro inventário crítico da televisão brasileira" cujos dados foram divulgados na Revista da ABEPEC, n. 4, de junho de 1978.

Especialmente, a partir dos anos 70, o desenvolvimento da área de comunicação está marcado pela abertura de centenas de cursos de graduação e pós-graduação; exigência de qualificação técnica exigida pelo mercado, governos e organizações, assim como a produção intelectual ampliando o conhecimento no campo da comunicação e suas interfaces. Inúmeras associações ${ }^{6}$, além das citadas anteriormente. São espaços de debates nacionais e internacionais em torno dos objetos tangenciados ou produzidos pela comunicação e são fundamentais para a consolidação teórica do campo, assim como diversos grupos de pesquisa registrados no CNPq, por exemplo.

No campo da política, a abordagem da comunicação em interface também passa a integrar o debate em sociedades científicas nacionais e internacionais. A Anpocs ${ }^{7}$, principal associação da área de Ciências Sociais abriga, atualmente, três grupos de trabalho oriundos do campo Comunicação e Política: Comportamento político, Opinião pública e Cultura

\footnotetext{
${ }^{4}$ ABEPEC (1973-1986) - Associação Brasileira de Ensino e Pesquisa em Comunicação. A data de 1986 é a mais próxima obtida em pesquisa.

${ }^{5}$ PUCRS - Pontifícia Universidade Católica do Rio Grande do Sul.

(IU ${ }^{6}$ ALCAR (2001) - Associação Brasileira de Pesquisadores de História da Mídia; SBPJor (2003) -Associação Brasileira de Pesquisadores em Jornalismo; ULEPICC (2004) - Capítulo Brasil da União Latina de Economia Política da Informação, da Comunicação e da Cultura; ABRACORP (2006) -Associação Brasileira de Pesquisadores de Comunicação Organizacional e Relações Públicas; ABCIBER (2006) - Associação Brasileira de Pesquisadores em Cibercultura; ABP2 (2010) - Associação Brasileira de Pesquisadores em Publicidade; e SOCICOM (2008) - Federação Brasileira das Associações Científicas e Acadêmicas de Comunicação.

7 ANPOCS (1977) - Associação Nacional de Pós-Graduação e Pesquisa em Ciências Sociais.
} 


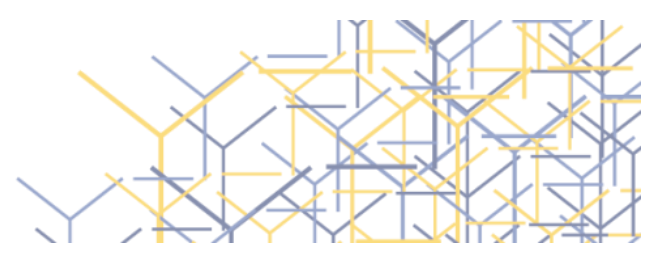

política; Internet, política e cultura e Mídia e política. No campo internacional, cabem citar as entidades ALAIC $^{8}$ e IAMCR $^{9}$, com grupos específicos sobre esta conjunção, comunicação, mídia e política.

A consolidação institucional do campo Comunicação e Política ocorre com a criação da Compolítica, sigla para a Associação Brasileira de Pesquisadores em Comunicação e Política, criada em dezembro de 2006, em Salvador (BA). Além de promover congressos bienais, realiza divulgação científica através de seu site e da revista Comunicação e Política. A título de ilustração, em 2019, o congresso reuniu 140 trabalhos em 10 Grupos de trabalho.

Finalmente, a recente conquista do campo está nos estudos sobre a Internet que estabelece novas interfaces com outros campos como engenharia, processamento de dados e etc. Das intrigantes reflexões sobre a Cibernética dos anos 70 ao romantismo da aldeia global do visionário Marshall McLuhan (1971), os estudos voltados à tecnologia, política e comunicação incidem sobre os regimes políticos, sobre a configuração do Estado e o comportamento da sociedade. Sob esta perspectiva que as pesquisas e pesquisadores justificaram a criação do INCT-DD, primeiro instituto nacional (CNPq) da área da comunicação, implantado em 2016, sob a sigla INCT-DD (Instituto Nacional de Ciência e Tecnologia em Democracia Digital $)^{10}$ que reúne instituições e pesquisadores nacionais e internacionais.

8 ALAIC (Caracas, 1978) - Asociación Latinoamericana de Investigadores de la Comunicación.

9 IAMCR (Unesco, 1948) - International Association for Media and Communication Research.

10 INCT-DD (2016) - Instituto Nacional de Ciência e Tecnologia em Democracia Digital, sediado na Universidade Federal da Bahia (www.inctdd.org.br), formado por 26 laboratórios e grupos de pesquisa de 20 instituições brasileiras; 23 centros internacionais de 23 instituições estrangeiras, incluindo três dos quatro maiores centros na área de democracia digital do mundo; 20 Programas de Pós-Graduação (stricto sensu) brasileiros nas áreas de Comunicação, Ciência Política, Administração, Direito, Ciência da Computação e Interdisciplinar; 51 professores-pesquisadores brasileiros e 36 professorespesquisadores estrangeiros. 
Como entende Rosanvallon (2006, p. 72), a Internet é uma forma social e política, na medida em pode ser a expressão da opinião pública e gerar participação política. As plataformas digitais conformam novas sociabilidades, novos modos de ver e participar, assim como possibilita às mídias tradicionais novos formatos e novos mercados. Se a televisão parecia alterar definitivamente as relações e resultados na política, a internet vem ampliar o poder midiático e tornar quase incontroláveis a área de abrangência, repercussão e resultados.

As mídias digitais introduziram profundas alterações para os estudos da comunicação, especialmente, no campo da comunicação política com o ingresso de novos atores e tecnologias protagonistas da realidade e visibilidade que exigiu métodos e competências para além da análise de estruturas e discursos, devido à força e singularidades comunicacionais das redes sociais, a atomização dos indivíduos, a ampliação da capacidade de comunicação das organizações públicas com acessibilidade e espaço para críticas e visibilidade. A crise da democracia é uma crise institucional, política, governamental e comunicacional.

\section{A comunicação do Estado}

Comunicação é um termo bastante recente na política. Ao Estado e ao poder de governos, reis e religiosos a palavra propaganda é a mais adequada para definir, historicamente, as relações de comunicação empreendidas. O poder, em grande medida, quer ser visto, e esta visibilidade importa ao campo de pesquisa que perscruta a forma de demonstração de poder, seja em tribos, monarquias, igrejas, em regimes totalitários e democracias. A encenação, dramatização definem as relações primevas de rituais e protocolos entre dominantes e dominados, governantes e governados, em tribos ou palácios para colocar o "poder em cena" (BALANDIER, 1982), que é a própria história da humanidade em suas celebrações e rituais marcados por símbolos, cores e objetos de ouro ou 
terra. Dos rituais e cerimônias de louvor ao poder sobre vida e morte à tecnologia digital contemporânea, o interesse científico persegue o comportamento, a identificação e a mensuração possível das reações, das mudanças da sociedade, dos indivíduos em relação à circulação de mensagens midiáticas, políticas com orientações e traduções sobre a vida e os modos de viver.

Historicamente, os estudos sobre o Estado privilegiam os processos de compreensão dos regimes políticos. Monarquias, Ditaduras e Democracias podem ser analisados a partir do mapeamento de relações de força e simbólicas entre Estado e sociedade, propaganda e produtos de comunicação utilizados para persuadir e dar visibilidade a ideologias, atores e projetos políticos. Os regimes totalitários subvertem a comunicação ao transformá-la em propaganda e espetáculos associados à coerção, censura e mecanismos obscuros. Há uma extensa produção sobre os regimes totalitários que, no uso da força, usaram mecanismos de dominação e sedução ancorados no discurso único e, assim, impactaram estudos da psicologia, sociologia, linguística e ciência política. Prevalece o silêncio da sociedade, das mídias e não há contraditório e, assim, a voz do Estado é amplificada para causar medo.

Nas democracias, as vozes da sociedade devem ser ouvidas e, assim, devem integrar explícita ou simbolicamente o discurso do Estado. 0 contraditório é evidenciado e a complexidade dos sistemas de comunicação das democracias é maior, embora menos estudado do que os totalitarismos. A opinião pública importa e é pontuada nas pesquisas e nas ruas. A produção de comunicação dos regimes democráticos é realizada em nome

<U do interesse público e, nesta direção, a força das democracias é medida pela liberdade de imprensa, autonomia das mídias e circulação de contraditórios. Os estudos sobre as teorias e culturas democráticas acoplaram a comunicação como parte de processos deliberativos, com evidência no Brasil às pesquisas de Maia (2008, 2012). O debate público e os resultados sobre temas controversos e sensíveis dependem de 


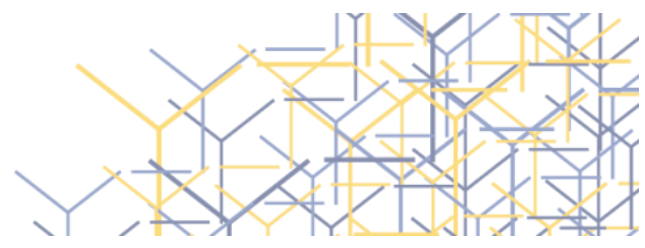

procedimentos comunicacionais e do acesso a meios digitais em determinadas plataformas ou redes sociais. Acontecimentos públicos essencialmente políticos, ou não - como eleições, tragédias ambientais e um impeachment, por exemplo, em uma democracia têm em seus procedimentos legais e na sua visibilidade, fatores que mobilizam o Estado, a mídia e a sociedade e não são compreensíveis se a participação da mídia não for incluída.

Nas últimas décadas, fenômenos comunicacionais desencadeados pela tecnologia e mídias digitais alteraram, decisivamente, a configuração das relações sociais e políticas, tão fortemente como ocorreu com o surgimento da imprensa, no século XV. Novas estratégias de comunicação das instituições e atores políticos se adaptam a lógicas da tecnologia que prime a visibilidade entre o tempo, tecnologia, ambientes, recursos, práticas e produtos imagéticos e discursivos que acionam códigos, acessos e controles do mundo digital. Cruciais são as análises em torno de visibilidade, opacidade, privacidade e a circulação de dados e informações pessoais, mercadológicos e políticos submetidos ou não à lógica democrática. Algoritmos, criptografia, robôs são algumas das instâncias que podem ser associadas a conceitos sobre cidadania, memória, política e comunicação.

A democracia digital, como a denominação indica, abrange procedimentos e tecnologias capazes de traduzir as dinâmicas de comunicação de instituições e atores políticos, das mídias e da sociedade. Poder-se-ia dizer, em hipótese, que há outra democracia obediente à constituição e, também, às tecnologias digitais. Em todas as dinâmicas

<U comunicacionais, a circularidade de informações em rede atinge públicos desejados, ou não, com repercussão incontrolável. As pesquisas têm se debruçado sobre processos de decisão e deliberação próprios da esfera pública, dita digital, abordando temas que apontam para a visibilidade quando relacionados a conceitos como transparência, acessibilidade, usabilidade, entendimento e auditabilidade de informações produzidas por 
instituições governamentais e políticas. De outro lado, os estudos sobre as tecnologias digitais utilizados que permite a autonomia e empoderamento de públicos, comunidades, minorias, movimentos e grupos sociais dedicados à produção e circulação de informações públicas, privadas ou mentiras. O INCT - Instituto Nacional de Ciência e Tecnologia em Democracia Digital é formado por pesquisadores nacionais e internacionais, com vasta produção publicada e está sob a coordenação de Wilson Gomes (2005, 2011).

O poder da comunicação digital interfere na própria democracia como bem demonstram os estudos sobre os dispositivos de intimidação jurídicopolítica (Lawfare) e a difusão de mentiras político-pessoais (fake news) com poder de alterar rumos da história. Por exemplo, a aprovação do Brexit (Reino Unido, 2016), a eleição dos presidentes Donald Trump (Estados Unidos, 2016) e Jair Bolsonaro (Brasil, 2018). Esse poder digital exige dos regimes políticos a adequação de leis, novas estruturas de comunicação e ambiência digital para a comunicação do Estado, com novos profissionais e tecnologias. Ao mesmo tempo, a intromissão privada de políticos e governantes é funcional para a governabilidade, assim oferecida como a comunicação direta, pessoal com governados e seguidores, em redes sociais, em posts, lives, tweets, memes estratégicos. Os achados desses estudos em Comunicação e Política indicam a complexidade das relações entre Estado, instituições e atores políticos, mídias e sociedade tensionadas pelo viés digital e novas metodologias que ultrapassam paradigmas tradicionais da ciência política e da comunicação.

A tecnologia digital, que caracteriza a contemporaneidade, incide <U sobre os regimes políticos de todos os matizes ideológicos e impõe ao campo constantes desafios teórico-metodológicos. Simultaneamente ao fortalecimento da comunicação institucional, a comunicação da sociedade e das mídias também é reorganizada, através de dispositivos digitais que viabilizam um protagonismo de atores privados em defesa de interesses particulares. Esta comunicação em redes digitais afeta, também, o 
comportamento e os resultados eleitorais numa democracia, assim como fortalece o autoritarismo. Ao mesmo tempo, quebra-se a narrativa hierárquica das instituições públicas e são borrados os limites entre mentiras e verdades veiculadas pela imprensa, pelo Estado e por grupos sociais.

Enquanto os regimes totalitários e as guerras fizeram uso da propaganda, do rádio, fotografia, cinema, imprensa e eventos espetaculares, combinando censura e persuasão, as democracias produziram sua visibilidade estratégica, associando comunicação aos princípios da propaganda e do marketing, especialmente depois da II Guerra, com a expansão cultural do capitalismo, a edificação das sociedades de consumo e a ocupação dos espaços nos meios de comunicação, especialmente, a televisão. Assim, foram convocados novos profissionais, além dos jornalistas, que organizaram assessorias e sistemas de comunicação governamental, estabelecendo relações com a imprensa e com a sociedade; elaborando políticas de Comunicação. Comunicação e visibilidade são exigências dos estados autoritários e democráticos, operacionalizadas através de políticas desenvolvidas por sofisticados sistemas com tecnologia e profissionais devidamente situados na burocracia estatal.

Na história da comunicação entre pessoas e poderes, ainda há um longo percurso para decifrar os complexos vínculos entre o que chamamos de comunicação e política, em tempos que nem era comunicação e muito menos política. O surgimento da imprensa no século XV desencadeou a possibilidade de registrar e difundir a palavra em larga escala, propiciando

<U o descontrole sobre a difusão do pensamento de qualquer ordem. A Reforma Protestante (1517) disso se beneficiou, assim como as guerras, o Renascimento, o Iluminismo.

O poder e a abrangência dos meios de comunicação massivos não substituem a dimensão espetacular do poder, mas sim fazem com que estes persigam a visibilidade prometida pelas mídias. Ainda como objetos de 
pesquisa, os acontecimentos públicos como a posse de governantes, celebrações, efemérides patrióticas e atos terroristas buscam a espetacularidade e, assim, são estudados tanto em regimes autoritários quanto democráticos, na medida em que servem a demonstrações de poder, coercitivo ou simbólico. Podem ser citados, também, estudos que demarcam este território e o definem como o "estado espetáculo" de Schwartzenberg (1978); a "sociedade do espetáculo" de Debord (1967); o "estado sedutor" de Debray (1994). Os governantes atuais buscam deixar registros mesmo obrigados a obedecer a leis e protocolos que privilegiam o interesse público. A tecnologia da televisão cria o modo de dar acesso aos espetáculos como as "telecerimônias" estudadas por Dayan e Katz (1995).

A espetacularidade da política depende da propaganda políticoideológica exercitada nas frentes de guerra e na sustentação de regimes políticos e governos. A propaganda é também o registro da história de dominações, revoluções e de manutenção de poder. Neste sentido, o papel da Igreja Católica e o Sacro Congregatio de Propaganda Fidae (1622) realizado para a Propagação da Fé, pelo mundo; a Revolução Francesa (1789) marcada em símbolos, cores, o hino Marselhesa, os jornais, os Clubes, as festas públicas, os cartazes, etc. A França lega à história da propaganda, também, os feitos do rei absolutista Luís XIV (1651-1715) chamado "rei sol", "rei-máquina" (APOSTOLIDES, 1993) devido ao investimento para cunhar sua imagem em todos os espaços de cultura, arquitetura e arte. De modo estruturado, o mais importante legado francês foi de Napoleão Bonaparte, entre 1799 e 1815, que criou a primeira estrutura planejada visando à propaganda dos seus feitos e sua imagem.

(U) Os regimes ditatoriais mantêm estruturas complexas de propaganda que abrangem arte, cultura, informação e são importantes para se entender os processos de persuasão e controle ideológico. Por exemplo, a Revolução Chinesa (1949) que mantinha o Ministério da Propaganda e a ideologia difundida por Quadrinhos e o cinema (LIU, 1978); o rádio na revolução 
Cubana (1959), a televisão no Brasil do regime militar, de 1964 a 1984 (WEBER, 2000).

De caráter libertário ou autoritário, a propaganda é instrumental e decisiva à visibilidade da ideologia de quem governa como parte da comunicação com a sociedade, e à persuasão quando é necessário obedecer ao projeto político, sob o controle do aparato policial. Os estudos sobre as relações entre arte, imprensa, propaganda e a promoção da ideologia são importantes para a compreensão da própria história. Os regimes políticos que cercaram a II Guerra exercitaram seus processos de dominação pela propaganda e pelo espetáculo, como analisa Tchakotine (1967) em sua obra seminal A mistificação das Massas pela Propaganda Política, de 1939, na qual compara o Nazismo da Alemanha ao Comunismo Soviético, através da reflexão behaviorista, explicitando os mecanismos persuasivos da propaganda, do espetáculo, dos símbolos e da informação. Os espetáculos fazem parte da agenda de estudos do campo comunicação e política assim como se transformaram em categoria crítica na análise da racionalidade e da passionalidade da sociedade e do Estado quando são acionadas paixões primárias como no populismo e no fascismo. Esta dimensão espetacular da comunicação serve, também, para identificar a quebra de princípios do jornalismo quando este se imiscui com o entretenimento e o marketing.

Democracias e ditaduras exercitam diferentes formas para se fazer ver, justificar o domínio em regimes totalitários, ou justificar a eleição nas democracias e, como tal, obter uma imagem pública favorável. Nas ditaduras, através da propaganda, manipulações e a censura que controlam o acesso a informações, manipulam a visibilidade e a opinião, enquanto que as democracias são demarcadas pela comunicação pública, a publicidade e o debate próprios da democracia. Nos regimes autoritários, as relações são simplificadas e controladas pelos aparatos repressivos, enquanto nas democracias as relações são complexas porque todos têm voz.

O Brasil atravessou duas experiências totalitárias de propaganda estratégica com o Estado Novo de Getúlio Vargas (1930-1945) e o poderoso 
DIP - Departamento e Imprensa e Propaganda (GARCIA, 1982) - e o regime militar brasileiro (1964-1984) com a AERP - Assessoria Especial de Relações Públicas - que inaugurou, a partir de 1968, a eficaz cumplicidade entre a ideologia "Segurança e Desenvolvimento" e a lógica do marketing, difundindo produtos comunicacionais potencializados pela televisão (WEBER, 2000). Amenizada por conceitos funcionais como propaganda governamental e marketing político, a lógica da persuasão política é mantida junto às estéticas publicitárias e qualificada pelos sistemas de comunicação, linguagens e mídias digitais.

Outra categoria possível é o "espetáculo político-mediático" (WEBER, 2013) constituído a partir de acontecimentos públicos que polarizam atenções, interesses, responsabilidades e a visibilidade do Estado, da mídia e da sociedade. Pode-se dizer que há uma combinação de interesses racionais, passionais e comunicacionais que adequam o acontecimento ao campo da política, da sociedade e das mídias. Como exemplos nacionais transformados em objetos de pesquisa, a Morte de Ayrton Senna (1994), a criação da Moeda Real (1994), eleição do presidente Luiz Inácio Lula da Silva (2002), as Jornadas de Junho (2013), o impeachment da presidenta Dilma Rousseff (2016), as tragédias ambientais de Mariana (2015) e Brumadinho (2019), em Minas Gerais; a tragédia da Boate Kiss em Santa Maria (RS), eleições presidenciais e outros.

A denominação comunicação institucional (comunicação estatal, comunicação governamental) designa as relações estabelecidas por governos e instituições políticas dos quais se espera comunicação, informações para atingir públicos específicos e a opinião pública. Nessa <U dimensão, as estratégias políticas de um governo garantem vultosos investimentos em estruturas tecnológicas e profissionais capazes de dar visibilidade e promover projetos políticos, partidários e pessoais. Estudar a comunicação institucional da política permite perscrutar o cumprimento ou não - dos princípios que atendem ao interesse público, através de produtos e atos comunicacionais. 


\section{A política e a comunicação midiática}

A publicidade (visibilidade) é princípio e obrigação das instituições e atores políticos que disputam espaço, apoio, votos, opiniões favoráveis e repercussão para seu projeto político, nas democracias. Esta visibilidade é provocada pelos mecanismos da comunicação institucional, mas depende, sobremaneira, daquela propiciada pelas mídias tradicionais e sociais e dispositivos tecnológicos. Em consequência, é preciso perscrutar as relações, disputas e pactos engendrados entre as organizações midiáticas e o Estado.

No campo da Comunicação e Política, podem ser identificados estudos voltados aos processos e produtos comunicacionais que obedecem às lógicas da propaganda, do marketing eleitoral e das mídias digitais, em acontecimentos, campanhas e disputas públicas e eleitorais. A confluência das mídias, especialmente a partir dos anos 80, permitiu que o analógico e o digital se encontrassem em meios de comunicação e organizações telefônicas, num sistema único. A combinação entre tecnologia, capital e estética gerou uma fórmula avançada de dependência da visibilidade midiática que embaralha informação jornalística, propaganda e entretenimento.

O jornalismo - campo historicamente consolidado - abriga estudos fundamentais na constituição do campo Comunicação e Política, devido à sua função histórica; à sua natureza voltada ao interesse público e ao fato de que política é a sua pauta principal. Do exercício do jornalismo político à cobertura definida por interesses editoriais e políticos, a imprensa exerce 0

(U) papel de vigilância sobre os poderes e o estudo sobre seu comportamento é fundamental para entender as relações estabelecidas com esses poderes, assim como o protagonismo da imprensa é delimitador da sua legitimidade. A cobertura da imprensa na transcrição da realidade e o seu exercício crítico formam a matéria essencial para a compreensão e consolidação dos regimes democráticos. O jornalismo já ultrapassou o jornal na forma 


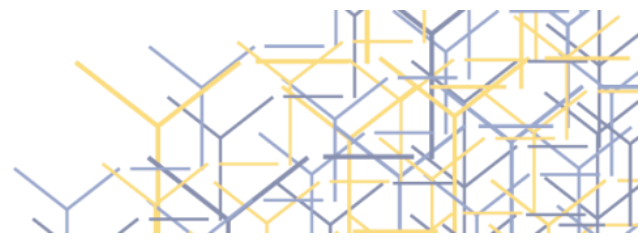

tradicional e, associado à tecnologia digital, vem ampliando sua abrangência, com nova linguagem e novos perfis profissionais, em operações multimídias. Até os currículos universitários se adaptaram a esta nova realidade, assim como a audiência.

O poder dos meios de comunicação e da imprensa reside no fato de se constituírem como espaços privilegiados de visibilidade associado a um tipo de ubiquidade que rapidamente colocam um fato em todos os espaços e audiências possíveis. Tudo está visível, e a tecnologia simplificou o acesso a todas as mídias, através da portabilidade e da disponibilidade de conteúdos. A cobertura do mundo entra por todos os buracos dos espaços que frequentamos, e nossas pequenas máquinas nos colocam dentro dos acontecimentos. No mundo digital, quaisquer informações podem ser armazenadas, revistas, recriadas, ressignificadas para novas audiências. Ao campo da Comunicação e Política interessam as relações de privacidade, acesso e participação dos atores sociais e políticas na produção, difusão e acesso à informação.

Os meios de comunicação tradicionais continuam a ocupar importante espaço na comunicação entre Estado e sociedade, em diferentes configurações e amplitudes. As organizações midiáticas se adaptaram às exigências tecnológicas e mantiveram intacto o jornalismo exercido em múltiplos formatos. Ao mesmo tempo, o mundo digital valorizou o entretenimento, a imagem, o cinema e, em meio a esta quantidade de informações, perde-se o controle de um programa e é ampliado o leque de opções para o leitor, espectador, ouvinte. Além desta amplitude, a tecnologia permite aos cidadãos criar e participar de acontecimentos e intervir a qualquer momento para opinar sobre qualquer tema em curso. A experiência comunicacional das democracias digitais amplia a capacidade de comunicação do Estado, dos governos, mas também a sobreposição de interesses privados sobre o público.

Diferente da visibilidade planejada estrategicamente pelas instituições e atores políticos, a visibilidade obtida no espaço midiático é Tríade, Sorocaba, SP, v. 8, n. 18, p. 6-48, setembro 2020 
indicativa do poder do ator político, por ocupar o espaço privilegiado de visibilidade que incide na formação e tensionamento de conceitos e preconceitos. A imprensa, que trabalha com a matéria da verdade e da realidade, contribui para a formação da imagem pública - favorável e desfavorável - de instituições e atores da política e, também, a todos os que buscam reconhecimento. A repercussão de um discurso governamental depende muito mais da imprensa do que de seu autor, e a visibilidade dada a este discurso depende de interesses editoriais e políticos. A autonomia e liberdade de imprensa estão no rol de defesa das democracias.

Da linotipo ao algoritmo, alguns exemplos da simbiose entre história, política e informação (comunicação/propaganda/notícia). A imprensa acompanha a Revolução Industrial (1760) e a Revolução Francesa (1789), duas das mais importantes rupturas para a humanidade. A palavra escrita tem o poder da visibilidade, neste momento, também, para fala da sociedade. A descoberta da fotografia (1826) estabelece outro tipo de registro de visibilidade e, a partir do surgimento do cinema (1895) e do rádio (1896), pode-se falar em comunicação, em meios de comunicação que passam a ser determinantes para a consolidação dos poderes da sociedade, do mercado e do Estado. A Guerra Civil norte-americana (18611865) é considerada um marco na cobertura jornalística como afirma Moretti (2004, p. 93). O fortalecimento do rádio e da imagem destinados à propaganda expõem a Revolução Russa (1918) e a sangrenta I Guerra (1914-1918) e indicam os caminhos históricos do campo Comunicação e Política. Na opinião de Gomes (2011, p. 337), "é um evento e não um autor, o que inicia o campo de pesquisa da comunicação e política como o

(U) conhecemos hoje. Este evento foi a $1^{\text {a }}$ Guerra Mundial e o emprego massivo de propaganda bélica e política pelos governos envolvidos no conflito". Também a II Guerra (1939-1945) utilizou todo o aparato dos meios de comunicação, especialmente, o rádio em consonância com os sistemas de propaganda, especialmente, os regimes nazista e comunista e as estruturas de comunicação da Inglaterra e Estados Unidos. Esse conflito bélico dividiu 
o mundo entre capitalismo e comunismo, ideologias em disputa durante a chamada Guerra Fria mantida entre Estados Unidos e União Soviética, simbolicamente terminada com o espetáculo da Queda do Muro de Berlim, em 9 de novembro de 1989.

O desenvolvimento do capitalismo foi impulsionado pela descoberta de novas tecnologias aplicadas à propaganda, à difusão do cinema, à popularização da televisão e à profissionalização da comunicação aliado à expertise de jornalistas, publicitários, relações públicas e marketing; escolas e produção científica. A disputa por visibilidade ganha com a televisão uma mídia síntese, na qual imagens e sons ultrapassam o mero formato de mídia para ocupar um lugar junto às pessoas. Sua popularização, a partir dos anos trinta, demarca as teorias da comunicação e amplia as questões sobre efeitos. A televisão causa sólidos impactos estéticos, sociais e políticos e solidifica o poder da comunicação massiva, impondo a instituições e atores políticos profunda adaptação à sua lógica de visibilidade e locução.

A televisão foi a mais fascinante e ainda instigante invenção do século $X X$, instalando-se entre a sociedade e a política, impulsionando a pesquisa em comunicação. De modo determinante, tornou mais complexos os objetos de estudos do campo comunicação e política. Não era mais suficiente estudar os sistemas políticos, governantes e seus discursos em diferentes mídias, na medida em que o objeto televisão se impõe como um espaço síntese de jornalismo, rádio, fotografia e cinema, embora estas instâncias mantenham sua autonomia estética e funcional. Outra mudança pela televisão é a junção fragmentada entre jornalismo, entretenimento e

<U propaganda; entre texto, voz e imagem que inauguram novas abordagens estéticas, linguísticas, semiológicas e ampliam a interdisciplinaridade nos estudos da comunicação. Para o campo da comunicação política, esta força introduz novas designações como videopolítica, telepolítica e o homo videns de Sartori (1998). O sistema democrático se curva à lógica da televisão e do marketing, ampliando a visibilidade dos poderes da república e suas 
disputas, assim como as mídias estabelecem novas relações com a cobertura política. Os debates políticos entre candidatos e a ocupação de espaço de propaganda eleitoral e a exposição obrigatória do Legislativo e Judiciário, no Brasil, transforma políticos e advogados em protagonistas de televisão e, assim, alteram o discurso, o debate e o espaço televisivo criando uma espécie de delitos estéticos (WEBER, 2000).

A imprensa, o rádio, a televisão e as mídias em redes digitais são estudadas como espaços de poder capazes de interferir nos movimentos da política, assim como cumprem as pautas de dar visibilidade aos poderes e de manter a vigilância que a democracia exige. A matéria jornalística é também indicativa do funcionamento das democracias. O estudo sobre agendamentos e enquadramentos que a imprensa promove sobre fatos, discursos e comportamentos afetos à política interpretam a sua interferência sobre estes. A censura imposta à imprensa, por exemplo, em regimes autoritários, oferecem hipóteses importantes sobre a ausência de registros que contariam a história de um período, da sociedade a da cultura. O silenciamento sobre a vigilância tem como consequência a oferta, apenas, de produtos comunicacionais gerados pelo próprio governo. A notícia política, censurada nos regimes autoritários e defendida, louvada nas democracias, como liberdade de imprensa, a própria tradução da democracia. Com inúmeras subdivisões, é ininterrupta a produção de informações sobre governos, partidos, atores políticos e instituições, temas políticos que sustentam as pautas, estruturas e profissionais da imprensa impressa, digital, rádios TVs e internet que, em diferentes abordagens editorais e estéticas, constroem narrativas importantes para a compreensão do mundo. Por outro lado, as mídias digitais e as plataformas de notícias inauguraram a quase impossibilidade de censura devido à simultaneidade de registros por profissionais de mídia, atores políticos, autoridades governamentais e qualquer cidadão disposto a participar. Perscrutar a linha de produção das notícias e sua capacidade de intervir na formação de opinião, assim como investigar sobre a modulação e a visibilidade de 
abordagem e enquadramento de temas políticos, permitem identificar as relações entre governos e mídias na definição e condução de governos, políticas públicas e outros fatos políticos. O poder dos meios de comunicação na história política - imprensa, rádio, televisão e internet permitiram arranjos diversos nas relações e visibilidades de poder.

À imprensa é conferida a autoridade - histórica e simbólica - de tornar visível a realidade e disputar a verdade com a legitimidade que tem a sua função social. Nesta direção, intervém no debate público e no discurso das instituições e atores políticos. Paralelamente ao seu trabalho e para além das notícias interage como organização empresarial junto ao mercado e ao Estado o que reforça seu papel na apropriação, tradução e difusão de acontecimentos. A visibilidade está associada à credibilidade e esta combinação é o ethos da imprensa e por isto desejado por instituições e atores políticos.

Atualmente, todos podem se comunicar e ter seu próprio canal de expressão da opinião, independentemente de ter qualidade ou de ser verdade. Assim, as mídias sociais digitais tornaram-se o centro de circulação de afetos, mobilizações, "tretas", agressões pessoais, arranjos e rupturas. Momentos de disputas de poder, como eleições, fortalecem plataformas como Whatsapp e Facebook ao introduzir, também, robôs com licença para repercutir mentiras e produzir fake news. Os poderes Legislativo e Judiciário debatem, atualmente, os procedimentos legais para coibir este tipo de crime.

\section{Em busca da Opinião Pública}

Opinião Pública e Comunicação Pública são conceitos imbricados quanto à comunicação e relações entre Estado, mídia e sociedade e integram a estrutura que suporta os estudos em comunicação política vinculados, historicamente, a rituais, comportamento da imprensa, propaganda política, acontecimentos públicos, eleições, reações da opinião 
pública, mobilizações sociais e à comunicação governamental. São temas que movimentam e consolidam o campo Comunicação e Política e, dentre elas, a comunicação pública é um dos mais recentes, na medida em que analisa fenômenos e a produção de comunicação do Estado, da mídia e da sociedade a partir do princípio normativo - Comunicação Pública - vinculado ao paradigma da "esfera pública" (HABERMAS, 2003).

As teorias sobre a influência possível das notícias, da propaganda, dos efeitos dos chamados meios de comunicação de massa e o próprio debate sobre a massa, públicos e a opinião pública ampliaram os estudos nas Ciências Sociais. A necessidade de um pensamento voltado aos desafios simbólicos e comportamentais gerados pelo poder da imprensa, da propaganda, do rádio, do cinema, da televisão e, finalmente, da internet, consolidou a comunicação como objeto de estudo. Psicólogos, filósofos, sociólogos, cientistas políticos, antropólogos, linguistas, debruçaram-se sobre fenômenos intermediados por objetos, linguagens e estéticas fascinantes, dos efeitos devastadores da propaganda nazista à capacidade de mobilização da internet. As mesmas questões, ou similares, mesmo tendo obtido muitas respostas, ainda se mantêm como problemas de pesquisa ao campo: como as pessoas e grupos são influenciados? Em que nível? Como participam de processos deliberativos? Cabem nesses estudos, também, a identificação de estratégias definidas por instituições e atores políticos, a partir de respostas a sondagens de opinião, em busca de imagem pública favorável, apoio, votos.

O percurso é marcado pelas tentativas de compreender o funcionamento da chamada "opinião pública" louvada, desejada ou negada, mas que serve de eixo ao debate sobre comunicação política. Gabriel Tarde (1992), já em 1901, na obra A Opinião e as Massas, problematizou os conceitos de "multidão" e "público" e as diferenças entre "opinião" e "conversação" em relação aos processos persuasivos, preocupado em definir o "público" quanto ao modo que surge, se desenvolve e se relaciona. O conceito Opinião Pública atravessa os séculos e inaugura as teorias 
democráticas e aquelas específicas à comunicação, especialmente, na junção entre a força da imprensa e a força persuasiva da propaganda. Como as pessoas são atingidas por uma notícia, discurso ou imagem? Qual é o efeito? Os resultados servem à manipulação ou ao estabelecimento de comunicação. A tentativa de apreender estes processos impulsionaram as teorias da comunicação em diagramas sobre efeitos.

Além de Tarde, dois outros pensadores são inaugurais na tradição teórica de debates sobre a opinião pública. Walter Lippmann (2008) manifesta em Public Opinion (1922) suas dúvidas quanto à eleição de um governo de qualidade baseada no poder da imprensa e nas opiniões formadas por estereótipos e preconceitos. Em contraposição, John Dewey (1946) defende em 1927 (The Public and its problemas), que as pessoas possuem discernimento para escolhas políticas. Os anos 20/30 são profícuos na elaboração das teorias sobre efeitos da imprensa sobre a sociedade, em meio a guerras. A linguagem e os símbolos circulantes na propaganda política são determinantes à pesquisa de Harold Laswell (1979), por exemplo, que em dezenas de publicações contribuiu, definitivamente, para o campo da comunicação, ao publicar, em 1948, o diagrama que circunscreve, mesmo simplificadamente, o ato comunicativo: Quem/ diz o quê/ em que canal/ para quem/ com que efeito?

Convivem a partir dos anos 50 e 60 diferentes abordagens de opinião pública relacionadas à imprensa, e às técnicas e estéticas das imagens, da propaganda e relações públicas circulantes na chamada sociedade de consumo. Conviviam os estudos críticos da Economia Política e Indústria Cultural com as pesquisas sobre as mediações e sentidos dos Estudos Culturais, a Linguística e a Semiótica.

As mudanças políticas do pós-guerra, o avanço do capitalismo cultural (JAMESON, 1997), a derrocada das democracias na América Latina nas décadas de 60/70, introduziram no campo da comunicação e da política, a problematização sobre o papel da televisão; a sedutora lógica publicitária nas eleições; o mecanismo de censura à imprensa e o silêncio da sociedade 
que fortalecem as teorias de controle e dominação da opinião pública. Como afirma Berger (2001, p. 241) sobre a pesquisa em comunicação na América Latina: "São demandas políticas e sociais, mais do que inquietações científicas, o que impulsiona a produção de conhecimento na América Latina $[\ldots]^{\prime \prime}$.

O conceito habermasiano de Esfera Pública fortalece a problematização sobre a opinião pública e o debate público e marca os estudos em Comunicação Política, assim como para as ciências sociais, especialmente nas reflexões de Gomes e Maia (2008). Também Pierre Bourdieu (1980) problematiza o campo ao defender a tese de que "a opinião pública não existe" já que a produção de opinião não está ao alcance de todos e nem todas têm o mesmo valor.

Dos efeitos da imprensa no século XIV à circulação de fake news no século XXI, o conceito de opinião pública enraizado na Revolução Francesa permite abordar o interesse público em oposição ao privado e ao individual para se compreender a evolução política do estado e das sociedades. A opinião pública é a resposta da sociedade aferida através da visibilidade, conversação e relações na desejada comunicação republicana. O comportamento da sociedade e a formação da opinião estudados sob os parâmetros da psicologia, sociologia e antropologia é complexificado quando pesquisadores da comunicação incluem incidências da cultura, símbolos e significados disputados entre as mídias e os poderes. A comunicação na e da sociedade interessa ao campo Comunicação e Política na medida em que os movimentos sociais e a mobilização são reações a políticas e decisões do Estado. Como parte da facilitação do mundo digital,

<U o povo vai às ruas, mais rapidamente e de modo desorganizado, mas momentaneamente eficaz como demonstraram ao Brasil, as Diretas Já (1992); Collor de Mello (1982); as Jornadas de Junho (2013); as ocupações de escolas (2014) e o impeachment de Dilma Rousseff (2016), por exemplo.

De preocupações simples sobre a persuasão que a imprensa e 0 Estado podem exercer desenhados em diagramas de efeitos e teorias da 
comunicação chegam-se - ainda neste século XXI - à necessidade de identificar efeitos, através de sofisticadas metodologias de captura de mensagens nas mídias digitais e redes sociais. O campo da comunicação política continua a responder, de modo cada vez mais interdisciplinar, a perguntas e achados sobre níveis de participação, persuasão, reações e controle da opinião pública, da opinião de grupos.

Decifrar a opinião pública é o desafio de origem das teorias da comunicação, associado às reações da sociedade e da política a partir da consolidação da imprensa e das teorias democráticas. Os regimes totalitários com seus espetáculos, propaganda e coerção instigaram pesquisadores como Tchakotine (1967), Reich (1974) e Canetti (1995), que deixaram importante legado conceitual para 0 entendimento da manipulação e controle das massas submetidas ao fascismo, nazismo, comunismo. Com os conceitos de massa e de opinião pública concorrem as novas mobilizações sociais do século XXI, definidas por Castells (2003) como movimentos transformadores de valores e instituições sociais, também são abordados em suas dinâmicas e repertórios, especialmente por Tilly e Tarrow (2008). Como exemplos, especialmente, a Primavera Árabe (2010); o 15M (15 de maio de 2011), na Espanha; e o Occupy Wall Street (2011), nos Estados Unidos. Com uma perspectiva deliberativa em redes sociais, estas ações parecem estranhas a sólidas teorias das ciências sociais.

Se hoje as massas parecem anacrônicas diante do conceito de "multidão" capaz de quebrar como paradigmas sobre como analisar a capacidade de organização e de relação com o Estado, como indicam Hardt

<U e Negri (2005), o movimento das ruas, as mobilizações se oferecem à compreensão de processos de manipulação e participação protagonizada por instituições, atores políticos e sociais, assim como por organizações midiáticas na medida em que o poder de comunicar é também o poder de operar os dispositivos tecnológicos. Como afirma Tarrow (2009, p. 181): 
"seja qual for a origem das reivindicações do confronto, são as oportunidades e restrições políticas que as transformam em ação".

A mesclagem cada vez mais complexa entre as mídias e linguagens; entre verdades e falácias; entre o interesse público e os interesses privados provoca as ciências sociais na problematização sobre os limites e poderes das mídias; da sociedade e das instituições políticas em meio às teias da comunicação digital. Cabe citar com contribuições lapidares para a análise de meios, efeitos e a opinião pública, ainda, Esteves (2011), Goffman (1992), McCombs e Waynberg (2009), Noelle-Neuman (2010) e citado por Gomes (2011, p. 340) as hipóteses sobre o "efeito de terceira pessoa e do efeito de priming da mídia (The third-person effect in communication) formulado por W. Phillips Davison, em 1983".

A complexidade na abordagem destes temas que mesclam comunicação política e opinião reside no embate permanente sobre a necessária visibilidade de ações e discursos de governantes e da sociedade. Duas dimensões principais de visibilidade podem ser ressaltadas: a institucional e a mediática. A primeira diz respeito à necessária visibilidade das instituições e atores públicos que mobilizam para esta finalidade, recursos de toda ordem na produção de produtos comunicacionais que, estrategicamente, mostrem o governo, suas ações e promovam seu projeto político. Trata-se da comunicação estratégica produzida e controlada, porquanto produzida pelas instituições dirigida a públicos e objetivos definidos. Numa democracia, o controle se dá nas etapas de produção e veiculação. O controle é parcialmente limitado às etapas de produção e difusão de comunicação. A repercussão de entrevistas coletivas, sites,

<U discursos, campanhas de propaganda e notícias é incontrolável numa democracia. Num regime autoritário, a produção e a circulação de informações (notícia e propaganda) podem ser controladas de maneira mais eficaz e de acordo com o desejo dos governantes. Mesmo sustentando o projeto político, através da coerção, os governos autoritários buscam uma 
imagem pública favorável, porquanto entendem que têm o poder absoluto sobre o modo de ver e de se fazer ver pela sociedade.

No descompasso e desalinho entre realidade e visibilidade, reside a imagem pública dos políticos, instituições e celebridades aferida continuamente por sondagens de opinião pública. Essa imagem vai sendo construída a partir dos fragmentos distribuídos por instituições e atores políticos interessados e intermediados pelas mídias, redes sociais ampliando a vulnerabilidade da mensagem original. Os resultados sobre a imagem pública desejada são instáveis, porque as informações emitidas pelos emissores são permeadas por outras opiniões, mensagens e pelo próprio destinatário. A busca de votos e opiniões obriga políticos e instituições a investir na sua imagem pública (WEBER, 2004). A opinião pública, a opinião dos públicos é a imagem pública e depende da circulação de informações e sentidos. A política e os políticos são cada vez mais reféns da sua imagem pública.

\section{A Comunicação Pública: Estado mídia e sociedade}

Diferentes e múltiplos processos e dispositivos de comunicação incidem sobre a visibilidade e o protagonismo de instituições e atores políticos, sociais e midiáticos, e o exercício de seus poderes em torno de pactos e disputas, em nome do interesse público. A inserção do conceito Comunicação Pública neste debate permite identificar e criticar esta comunicação a partir do paradigma da esfera pública (HABERMAS, 2003) e da perspectiva de Esteves (2011). A Comunicação Pública tem caráter normativo e, como tal, deve ser operacionalizada nas estratégias, mídias e produtos do Estado democrático, assim como o debate público deve ser entendido como o seu processo constitutivo.

A Comunicação Pública é da ordem da normatividade e em seus diferentes formatos pode ser entendida como parâmetro de qualidade das democracias contemporâneas, considerando que o interesse público é 
fundante das decisões do Estado republicano e decisões sobre políticas públicas que atingem saúde, trabalho e educação, por exemplo, dependem da opinião da sociedade e da circulação de opiniões múltiplas pelas mídias. Entende-se a comunicação pública como instância de circulação de informações de interesse público; debates, de trocas de opiniões e informações em variados formatos, desde que indiquem a circulação e a decisão sobre argumentos em prol do interesse público, nas esferas de visibilidade pública, assim definida por Gomes e Maia (2008) ao ampliar a perspectiva habermasiana para o debate contemporâneo. A Comunicação Pública, como expressa a obra Comunicação Pública e Política - pesquisa e práticas (WEBER; COELHO; LOCATELLI, 2017) é o conceito que permite analisar o comportamento do Estado, da mídia e da sociedade instados por fenômenos, temas e por sistemas públicos de comunicação e radiodifusão.

Os fenômenos analisados pela Comunicação Pública abrangem os acontecimentos públicos (QUÉRÉ, 2011) determinados por mortes e doenças decorrentes de fenômenos ecológicos naturais ou provocados, como enchentes, terremotos, desabamentos; fenômenos criminosos, como as guerras, atos terroristas, incêndios; fenômenos de saúde pública como epidemias, pandemia; mortes célebres. Os acontecimentos públicos definidos pela vida e celebração estão relacionados a eleições, mudanças sociais, reformas constitucionais, conquistas, incluindo casamentos e nascimentos na monarquia.

Os temas de interesse público analisados pela ótica da Comunicação Pública são desencadeadores de debates, porquanto são capazes de mobilizar a sociedade na medida em que atingem diretamente a vida de cada cidadão e a vida da coletividade. São temas sensíveis, vitais, que quando enfrentados pelo poder públicos acionam preconceitos, formação cultural, moral religiosa, princípios éticos, tais como aborto, racismo, questões de gênero, sexualidade, maioridade penal e outros. O "interesse público é a marca retórica dos discursos e das práticas das democracias embora, a sociedade possa ser alijada das decisões sobre temas de 
interesse público", então, o uso estratégico deste conceito "pode mascarar e subverter ações de interesse privado [...], privilegiando determinados governantes e seus dependentes familiares ou políticos" (WEBER, 2017, p. 28).

Ainda como instâncias de produção da Comunicação Pública estão os sistemas de comunicação do Estado e seus poderes (Executivo, Legislativo e Judiciário). A produção de informações e propaganda por mídias e órgãos estatais em uma democracia deve, simbólica e constitucionalmente, ser norteada pelo interesse público. Os dispositivos digitais, a partir dos anos 90, ampliaram a possibilidade de transparência e acesso a canais de participação que, utopicamente, permitiriam uma democracia mais participativa. Mas nem sempre a qualidade das mídias é proporcional à qualidade dos políticos e governantes e seus interesses. Não cabe relacionar Comunicação Pública aos regimes autoritários, na medida em que a opinião pública, a sociedade, a imprensa estão sob censura. Mas, nos jogos retóricos, os mais caros princípios da civilização - a democracia - podem ser subjugados a narrativas próprias à propaganda governamental. Como exemplo, a primeira "Política de Comunicação Social" que promovia os direitos humanos, a democracia e a liberdade de expressão formulada pelo governo Médici (1970-1973), cujas ações eram tragicamente opostas a isso (WEBER, 2000). A comunicação do Estado republicano deve ser regida por uma comunicação pública determinada pelo interesse público como rege a Constituição Federal de 1988.

As pesquisas vinculadas ao conceito Comunicação Pública dedicamse à análise de ações, discursos, produtos, mídias e à publicidade dos

<U poderes Judiciário e Legislativo; aos debates públicos causados por temas de interesse público e ao estudo de acontecimentos públicos que necessariamente convocam o Estado, a sociedade e as mídias à responsabilidade, providências e manifestações. São estudos norteados pela identificação e crítica sobre a participação dos poderes públicos, da sociedade e da mídia. Os desafios operacionais deste tipo de pesquisa 
residem na singularidade e poder dos diferentes processos, tecnologia e produtos próprios à comunicação institucional, à comunicação midiática e à comunicação societal. A qualidade das democracias é diretamente proporcional à qualidade de participação dos cidadãos. Essa participação em reuniões, mídias digitais ou nas ruas é um significativo complicador para o Estado, já que, mesmo tendo à sua disposição mídias, profissionais, e tecnologia que facilitam o debate, há um crescente isolamento próprio do descrédito e personalização da política e, consequentemente, a incidência de interesses privados sobre o que é público.

A perspectiva da Comunicação Pública vinculada ao paradigma da esfera pública contém algo de resistência sugerida pela práxis e é importante e transformadora para o Estado, as mídias e a sociedade. Significa dizer que "a sociedade fala e se manifesta em torno de políticas públicas; em situações sociais limítrofes como a criminalidade, a pobreza, o desemprego, a falta de assistência médica; o reconhecimento de novas configurações familiares, sexuais, culturais; o posicionamento sobre temas polêmicos como o aborto, eutanásia; as reivindicações por justiça, igualdade, liberdade e, as manifestações relacionadas à vigilância dos poderes" (WEBER; COELHO; LOCATELLI, 2017, p. 24).

Este debate público, no entanto, sempre será passível de enquadramentos definidos pela imprensa; sempre poderá ser mote de negociações e manipulado pela retórica dos poderes republicanos (WEBER; COELHO; LOCATELLI, 2017, p. 31), na medida em que "o poder do discurso político está na abordagem de temas de interesse público expostos publicamente como notícia, propaganda, diálogos e ações de relações

<U públicas". A circulação de temas de interesse público e sua transformação em debate público é proporcional à mobilização provocada por acontecimentos públicos que provocam tensões passionais e racionais dos públicos envolvidos da mídia e do Estado em debates sobre temas vitais. Estes públicos podem ser estudados na sua organização em redes para se posicionar, se fortalecer em relação a determinado acontecimento, 
denominadas de Redes de Comunicação Pública (WEBER; COELHO; LOCATELLI, 2017, p. 46-47) que se movimentam em busca de "visibilidade, apoio, mudanças, leis e votos que exigem negociações e decisões políticas" e contêm potência para intervir e deliberar. Estas redes obedecem a uma tipologia que abrange três âmbitos; no Estado com "poder legal de governar e intervir", as redes de comunicação específicas aos poderes Executivo, Legislativo e Judiciário, além dos "Sistemas de Comunicação e Radiodifusão Pública". No âmbito da sociedade, que detém "o poder passional e ideológico de organização e manifestação", funcionam as redes de Comunicação Política, Social, Mercadológica, Científico-educacional e Religiosa. As organizações mediáticas que detêm "o poder de visibilidade e centralização" são estudadas na sua diversidade (profissionais, digitais, alternativas) como as "Redes de Comunicação Mediática".

Cada uma das redes de comunicação tem estratégias e públicos específicos e seu poder de intervir está na visibilidade que suas demandas e discursos obtêm e podem ser estudadas quanto à sua força a partir de três estratégias a saber legitimidade, visibilidade e credibilidade. Neste sentido, a legitimidade mensura "a capacidade de liderança, de representação e de reconhecimento por diferentes instâncias, direta e indiretamente implicadas no debate"; a visibilidade indica competências no uso de "dispositivos de propaganda, mídias e informação, adequados a linguagens e formulações discursivas próprias da lógica publicitária, mediática ou do público em questão" e, a credibilidade é a consequência do processo quando a demanda da rede recebe o reconhecimento quanto aos seus "argumentos por instâncias com legitimidade sobre o tema em

<U questão". (WEBER; COELHO; LOCATELLI, 2017, p. 54-55).

A Comunicação Pública é a instância que reúne e fortalece as outras dimensões da comunicação que incide sobre a política (institucional, midiática e societal), na medida em que pode definir a qualidade da democracia, através da promoção de um debate público sobre temas essenciais e da operação deste conceito em políticas públicas, campanhas 


\section{tríade}

de instituições públicas e discursos governamentais norteados pelo interesse público.

\section{Considerações finais}

A comunicação da política e a comunicação sobre a política interessam a todos que são afetados por suas decisões e discursos mantidos por sofisticadas burocracias dos órgãos estatais, exposta ininterruptamente pelas mídias profissionais e redes sociais. A instantaneidade e a difusão mobilizam pesquisadores em busca da compreensão destas comunicações, através de sofisticadas tecnologias de captura e mensuração. Convivem com a análise de material histórico, entrevistas e decupagens de vídeos, por exemplo. Os achados das pesquisas do campo Comunicação e Política têm a pretensão de contribuir para a compreensão das relações entre os regimes políticos, meios de comunicação e sociedade, em meio a novas práticas das democracias em roupagem totalitária; ao domínio do capitalismo sobre estas democracias e as multidões; a sociedade aparece sob diversas configurações à direita e à esquerda e os meios de comunicação se apresentam sob diferentes formatos e amplitudes em competição com as mídias digitais.

Vive-se um período de total conexão com o mundo e total acirramento de paixões. Sabemos de tudo, mas isso não significa que possamos fazer algum movimento.

O campo se fortalece a partir de pesquisas sobre as relações entre comunicação, política e sociedade estabelecidas a partir de processos e estratégias de interesse público e privado; sobre o poder do Estado, dos meios e tecnologias de comunicação e o poder da sociedade para o estabelecimento destas relações e dinâmicas comunicacionais essenciais à consecução de objetivos políticos, econômicos e culturais. Trata-se de estudar o poder em suas diferentes formas e exercícios: o poder simbólico; o poder das massas e da sociedade; os pactos e disputas de poder em torno 
de ações vitais e temas de interesse público; e os processos de persuasão e coerção e dominação dos poderes governamentais e seus fenômenos.

O desenvolvimento da comunicação digital disponível para os poderes e a sociedade, em redes sociais, exige novas metodologias e tecnologias que permitam estudar o engajamento cívico diferenciado, o chamado ativismo digital que marca esta década. Além disto, estudar a participação política das manifestações públicas, mobilizações sociais e lutas por identidade e representação, de gênero, meio ambiente, questões raciais, infância, estabelecem um patamar diferenciado para compreender uma sociedade. Estas questões estão relacionadas também a eleições e disputas parlamentares que ativam pesquisas, estudos sobre comportamento individual e social, assim como os processos de definição do voto. O comportamento da opinião pública é sempre instigante: quais são os valores, as crenças, os medos e o conhecimento que influenciam o comportamento político e social? Como ocorre a formação da opinião e qual o nível de influência em pesquisas e nas eleições, na formação da imagem pública?

Pode-se registrar nestas considerações finais uma hipótese baseada na eminência da comunicação sobre a política, ora como propaganda, como espetáculo. De acordo com a história ocidental não há nenhum momento em que não seja necessária a simbologia, o signo, a palavra, a estética para traduzir, para expor, para dar visibilidade ao poder. Assim como os rituais vão conformando a extensão e marcando os poderes, os meios de comunicação impressos, eletrônicos e digitais são a criação da humanidade para criar novos poderes e novas designações destes, qual poder

(U) concorrente. Se a sociedade na primeira dimensão tem a passividade necessária à obediência e nesta segunda dimensão ingressa como espectadora qualificada, mensurada, na terceira dimensão da evolução das mídias - o mundo digital - permite que ela se integre, produza e possa competir nas suas linguagens. 
Atores e instituições são submetidos à dramatização e a exercícios diários para persuadir e informar sobre suas qualidades, para se tornarem críveis. A Internet alterou as relações entre política, sociedade, meios de comunicação e os regimes políticos e impôs uma modalidade de comunicação à quais todos podem ter acesso.

\section{Referências}

APOSTOLIDËS, Jean-Marie. O rei-máquina - Espetáculo e política no tempo de Luís XIV. Rio de Janeiro: J.Olympio; Brasília: EDUNB,1993.

ARENDT, Hannah. A Vida do Espírito - o pensar, o querer, o julgar. Rio de Janeiro: Relume Dumará.1992.

BALANDIER, Georges. O poder em cena. Brasília: Ed. Universidade de Brasília, 1982.

BERGER, Christa. A Pesquisa em Comunicação na América Latina. In: HOHLFELDT, Antonio; MARTINO, Luiz C.; FRANÇA, Vera. (Org.). Teorias da Comunicação. Conceitos, escolas e tendências. Petrópolis: Vozes, 2001. p. 241-277.

BOURDIEU, Pierre. A opinião pública não existe. In: THIOLLENT, Michel (Org.). Crítica Metodológica. Investigação Social e enquete operária. São Paulo: Polis, 1980. p.137-151.

BOURDIEU, Pierre. Algumas propriedades dos campos. In: BOURDIEU, Pierre. Questões de sociologia. Rio de Janeiro: Marco Zero, 1983. p. 89-94.

BOURDIEU, Pierre. L'emprise du journalisme. Actes de la Recherce em (U) Sciences Sopciales, Seuil, n.101/102, p. 3-9, mar. 1994.

$(1$ CANETTI, Elias. Massa e poder. São Paulo: Companhia das Letras, 1995.

CAPARELLI, Sérgio. Televisão e Capitalismo. Porto Alegre: L\&PM, 1982. 
CASTELLS, Manuel. Ruptura - A crise da democracia liberal. Rio de Janeiro: Jorge Zahar, 2003.

ChARAUdeAU, Patrick. Discurso Político. São Paulo: Contexto, 2006.

DAYAN, Daniel; KATZ, Elihu. La história em directo - la restransmissión televisiva de los acontecimentos. Barcelona: G.Gilli, 1995.

DEBORD, Guy. A sociedade do espetáculo. Lisboa: Afrodite, 1967.

DEBRAY, Régis. O Estado sedutor. Petrópolis: Vozes, 1994.

DEWEY, John. The public and its problems - na essay in political inquiry. Chicago: Gateway Books, 1946.

ESTEVES, João Pissarra. Sociologia da Comunicação. Lisboa: Fundação Calouste Gulbenkian, 2011.

GARCIA, Nélson Jahr. O Estado Novo: Ideologia e Propaganda Política a legitimação do estado autoritário perante às classes subalternas. São Paulo: Loyola, 1982.

GOFFMAN, Erving. A representação do eu na vida cotidiana. Petrópolis: Vozes, 1992.

GOMES, Wilson. A democracia digital e o problema de participação civil na decisão política. Revista Fronteiras, São Leopoldo, v. 7. n. 34, p. 214222, 2005.

GOMES, Wilson. 90 Anos de Comunicação e Política. Revista Contemporânea, Salvador, v. 9, n. 3, p. 337-343, 2011.

GOMES, Wilson; MAIA, Rousiley. Comunicação e Democracia:

Problemas e Perspectivas. São Paulo: Paulus, 2008.

HABERMAS, Jürgen. Mudança estrutural da esfera pública. Rio de Janeiro: Tempo Brasileiro, 2003. 


\section{tríade}

HARDT, Michael; NEGRI, Antonio. Multidão: guerra e democracia na era do Império. Rio de Janeiro: Record, 2005.

JAMESON, Friedric. A Lógica Cultural do Capitalismo Tardio. São Paulo: Ática, 1997.

LASSWELL, Harold. A linguagem da política. Brasília: UNB, 1979.

LIPPMANN, Walter. Opinião pública. Petrópolis: Vozes, 2008.

\section{LIU, Alan P. L. Comunicación e Integración Nacional en la China}

Comunista. Barcelona: Gustavo Gili, 1978.

MAIA, Rousiley. Mídia e deliberação. Rio de Janeiro: Editora FGV, 2008.

MAIA, Rousiley. Deliberation: the media and polítical talk. New York: IAMCR, 2012.

MARTINO, Luís Mauro Sá. Além do paradigma: propaganda política e democracia em seis artigos de Harold Lasswell. Interin, Curitiba. v. 13, n. 1 , jan./jun. 2012.

MCCOMBS, Maxwell; WAYNBERG, Jacques. A teoria da agenda: a mídia e a opinião. Petrópolis: Vozes, 2009.

MCLUHAN, Marshall; FIORE, Quentin; AGEL, Jerome. Guerra y paz em la aldea global. Barcelona (ES): Martinez Roca, 1971.

MELO, José Marques. Circunstâncias que marcaram o percurso de um Jornalista/Pesquisador pelo Campo das Ciências da Comunicação. In: LOPES, Maria Immacollatta de Vassallo (Org.). Epistemologia da comunicação no Brasil: trajetórias autorreflexivas. São Paulo: ECA-USP, 2016. p. 69-100.

MORETTI, Marco Aurélio Morrone. A ética no jornalismo: o jornalismo em tempos de guerra. Cenários da Comunicação, São Paulo, v. 3, p. 89102, dez. 2004. 
NOELLE-NEUMANN, Elisabeth. La Espiral Del Silencio: Opinión pública: nuestra piel social. Buenos Aires: Paidós, 2010.

QUÉRÉ, Louis. A individualização dos acontecimentos no quadro da experiência pública. Caleidoscópio, Lisboa, n. 10, p. 13-37, 2011.

REICH, Wilhelm. Psicologia de massa do fascismo. Porto: Publicações Escorpião, 1974.

ROSANVALLON, Pierre. La contre-démocratie: la démocratie à l'âge de la défiance. Paris: Seuil, 2006.

RUBIM, Antônio A. C.; AZEVEDO, Fernando Antonio. Mídia e Política no Brasil. Lua Nova, São Paulo, v. 1, n. 43, p. 189-216, 1998.

SARTORI, Giovanni. Homo Videns - la sociedad teledirigida. Buenos Aires: Taurus, 1998.

SCHWARTZENBERG, Roger-Gérard. O estado espetáculo. São Paulo: DIFEL, 1978.

TARDE, Gabriel. A opinião e as massas. São Paulo: Martins Fontes, 1992.

TARROW, Sidney. 0 poder em movimento: movimentos sociais e confronto político. Petrópolis: Vozes, 2009.

TCHAKHOTINE, Serge. A Mistificação das Massas pela Propaganda Política. Rio de Janeiro: Civilização Brasileira, 1967.

TILLY, Charles; TARROW, Sidney. Politique(s) du conflict: de la grève à la révolution. Paris: Sciences Po, 2008.

WEBER, Maria Helena. Ditadura \& Sedução (Redes de Comunicação e Coerção no Brasil - 1969/1973). In: WEBER, Maria Helena. Comunicação e Espetáculos da Política. Porto Alegre: Ed. UFRGS, 2000. p. 139-216. 
WEBER, Maria Helena. Do acontecimento público ao espetáculo políticomidiático. Caleidoscópio, Lisboa, n. 10, p. 189-203, jun. 2013.

WEBER, Maria Helena. Imagem Pública. In: RUBIM, Antonio Albino Canelas. Comunicação e Política - conceitos e abordagens (Org.). Salvador: Edufba, 2004. p. 259-307.

WEBER, Maria Helena. Visibilidade e credibilidade: tensões da comunicação política. In: MAIA, Rousiley; CASTRO, Maria Ceres S. (Org.). Mídia, esfera pública e identidades coletivas. Belo Horizonte: Editora UFMG, 2006. p. 117-136.

WEBER, Maria Helena. Nas redes de comunicação pública, as disputas possíveis de poder e visibilidade. In: WEBER, Maria Helena; COELHO, Marja Pfeifer; LOCATELLI, Carlos (Org.). Comunicação Pública e Política - pesquisa e práticas. Florianópolis: Insular, 2017. p.23-56.

WEBER, Maria Helena; COELHO, Marja Pfeifer; LOCATELLI, Carlos (Org.). Comunicação Pública e Política - pesquisa e práticas. Florianópolis: Insular, 2017. 